\title{
XIV. On the adhesion of glue
}

\section{B. Bevan Esq.}

To cite this article: B. Bevan Esq. (1826) XIV. On the adhesion of glue , Philosophical Magazine Series 1, 68:340, 111-112, DOI: 10.1080/14786442608674094

To link to this article: http://dx.doi.org/10.1080/14786442608674094

曲 Published online: 10 Aug 2009.

Submit your article to this journal 준

Џll Article views: 3

Q View related articles $₫$ 
tained a contrary opinion, we considered that the publication of our experiments might not prove altogether useless.

The compression of liquid bodies reducible to drops, is, as far as our experience yet goes, subject to the same law. Here too, the compression and the compressing power seem to bear a direct relative proportion. We may therefore assume, that the gases converted into-liquids reducible to drops, begin again to follow the same law to which they answered as gases. If this should be confirmed by further experiments, it may be said that the compression of a body ceases to conform to these rules, only in its moment of transition from one state of aggregation to another.

\section{On the Adhesion of Glue. By.B. BevaN, Esq.}

\section{To the Editor of the Philosophical Magazine and Journal.} Sir, FXPERIMENTS, when carefully made on the properties I of substances which are daily used in large quantities, cannot be altogether uninteresting, but may lead to improvements in the arts.

Having for some years been in possession of apparatus for measuring with accuracy mechanical forces to a considerable extent, I avail myself of a leisure hour, when I carn find one, of trying various elementary experiments. I have lately tried the force of adhesion of common glue. The method $\mathbf{I}$ adopted was that of gluing together two cylinders of dry ash wood, of $1.5 \mathrm{in}$. diameter, and about eight inches long: these were submitted to the lever apparatus after being glued together twenty-four hours. To separate the cylinders required a force of 1260 pounds; and as the area of the circular ends of the cylinders were $1 \cdot 76$ in., it follows that the force of 715 pounds would be required to separate one square inch. It is right to observe that the glue used in this experiment was fresh made, and the season very dry. Upon referring to some former experiments on this substance, made in the winter season, and upon glue which had been frequently melted, with occasional additions of glue and water, I obtained a result of 350 to 560 pounds to the square inch. My present experiment was conducted upon a larger scale, and with greater care in the direction of the resultant of the force, so that it might be, as near as was practicable, in a line passing at right angles, through the centres of the surfaces in contact; the pressure was applied gradually, and was sustained two or three minutes before the separation took place. 


\section{2 Mr. Tredgold on the Theory of Hydro-dynamics.}

Upon examining the separated surfaces, the glue appeared to be very thin, and did not entirely cover the wood, so that the actual cohesion of glue must be something greater than 715 pounds to the square inch.

I also tried the lateral cohesion of fir-wood, from a Scotch fir of my own planting, cut down in the autumn of 1825, and sawn into boards, being at the time of this experiment quite dry and seasoned. The force required to separate the wood was 562 pounds to the square inch; so that if two pieces of this wood had been well glued together, the wood would have yielded in its substance before the glue.

The cohesion of Memel fir, across the grain, I have found to be from 540 to 840 pounds to the square inch, on a specimen tried some time ago, the modulus of elasticity of which in the same position of the grain, varied from 40,500 to 44,600 pounds; and the modulus of elasticity of the Scotch fir timber used in the experiment above described, was 24,600 pounds.

I also tried the force required to break, or tear out, a halfinch iron pin, applied in the manner of a pin to a tenon in the mortice; the thickness of the board being $0.87 \mathrm{in}$. and distance of the centre of the hole from the end of the board $1.05 \mathrm{in}$.; - the force required was 976 pounds. As the strength of a tenon, from the pin-hole, may be considered in proportion to the distance from the end, and also as the thickness; we may, for this species of wood, obtain the breaking force in pounds nearly, by multiplying together one thousand times the distance of the hole from the end, by the thickness of the tenon in inches. I am, dear sir, yours truly,

\section{B. Bevan.}

P.S. From an experiment subsequently made on solid glue, $I$ find the cohesion to be 4.000 pounds to the square inch, from which it may by inferred that the application of this substance as a cement is susceptible of improvement.

B. B.

XV. Researches on the Theory of Hydro-dynamics. By Thомas Tredgold, Esq. Civil Engineer.

[Second Communication.]

Prop. 1. - THE resistance to the motion of a body in a fluid is equal to the quantity of motion it impresses on the fluid.

For, if the quantity of motion were greater than the resistance, the effect would be greater than the power producing it, and if it were less, the resistance would be greater than the resisting forces. 